
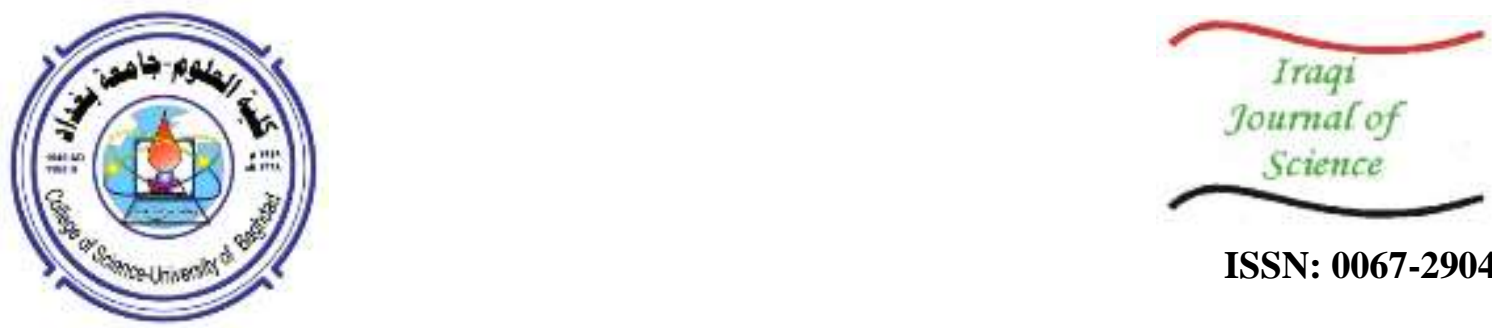

ISSN: 0067-2904

\title{
Fish Assemblage Structure in Al-Huwaizah marsh southern of Iraq after inscribed on the World Heritage List
}

\author{
Basim M. Hubain Al-Thahaibawi ${ }^{1}$, Kadhim H. Younis ${ }^{2}$, Ithar K.A.Al-Mayaly ${ }^{1}$ \\ ${ }^{1}$ Department of Biology, College of Science, University of Baghdad, Baghdad, Iraq \\ ${ }^{2}$ Department of Marine Vertebrates, Marine Science Centre, University of Basra, Basra, Iraq
}

\begin{abstract}
The fish assemblage structure in Al-Huwaizah marsh, southern of Iraq was assessed. Fish samples collected monthly by different fishing means from period December 2017 to November 2018. A total of 28959 individual of fish belonging to 9 families and 19 species were collected, 11 of them of native species and 8 of alien species. The numerical dominance index value (D3) of the highest three abundant species comprised $74.26 \%$ of the total fish caught, included Planiliza abu (AlKeshny) $38.2 \%$; Coptodon zilli (Tilapia red abdomen) $29.41 \%$ and Carassius auratus (Prussian carp) 6.65\%. The total weight of fish caught 2,190,680 tan, highest weight $312,242 \mathrm{~kg}$ achieved in July, while lowest weight $41,590 \mathrm{~kg}$ found in September. The weight dominance index value (D3) of the highest three species in weight recorded 1,409,973 tan of the total weight of fish caught included C. zilli (Tilapia red abdomen) $659,994 \mathrm{~kg}$, S. triostegus (Jerry fresh water) $495,784 \mathrm{~kg}$ and O. aureus (Blue tilapia) $245,195 \mathrm{~kg}$.The annual rate value for diversity, richness and evenness indices amounted 1.88, 1.75 and 0.64 , respectively. Some of physical and chemical properties were studied such as water temperature which ranged from $11.5^{\circ} \mathrm{C}$ in January to $31.02^{\circ} \mathrm{C}$ in August month, dissolved oxygen ranged from 2.24 $\mathrm{mg} / \mathrm{l}$ in September to $9.9 \mathrm{mg} / \mathrm{l}$ in February, salinity varied from $1.37 \%$ in November to $3.76 \%$ in September and $\mathrm{pH}$ which ranged from 7.4 in June to 8.15 in December. Jaccard Similarity Index (Ss\%) was used to know the similarity degree between the monthly catch samples. Also associations between distribution of fish species and the environmental variables were quantified by using canonical correspondence analysis (CCA).
\end{abstract}

Keywords: Fish assemblage, ecological factors, biodiversity indices, Al-Huwaizah marsh, Iraq

\section{تركيبة تجمع الاسماك في هور الحويزة جنوب العراق بعد ادراجه على لائحة التراث العالمي}

$$
\begin{aligned}
& \text { باسم عحم حبين الذهيباوي" "1، كاظم حسن يونس ² إيثار كامل عباس الميالي } 1
\end{aligned}
$$

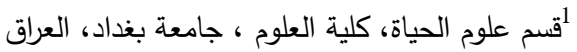

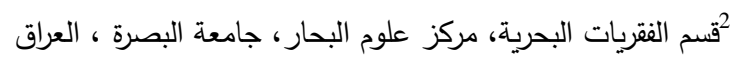

$$
\begin{aligned}
& \text { تم تقييم تركيبة تجمع الأسماك في هور الحويزة جنوب العراق. جمعت عينات الأسماك شهريًا بوسائل }
\end{aligned}
$$

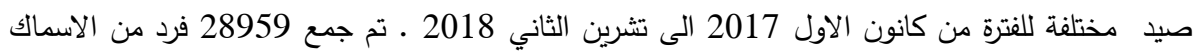

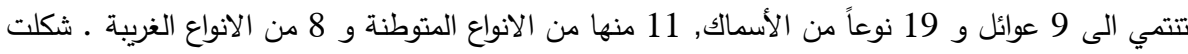

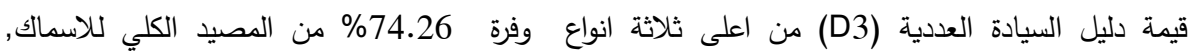

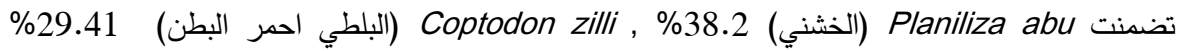

\footnotetext{
* Emil: Basim_moh74@yahoo.com
} 


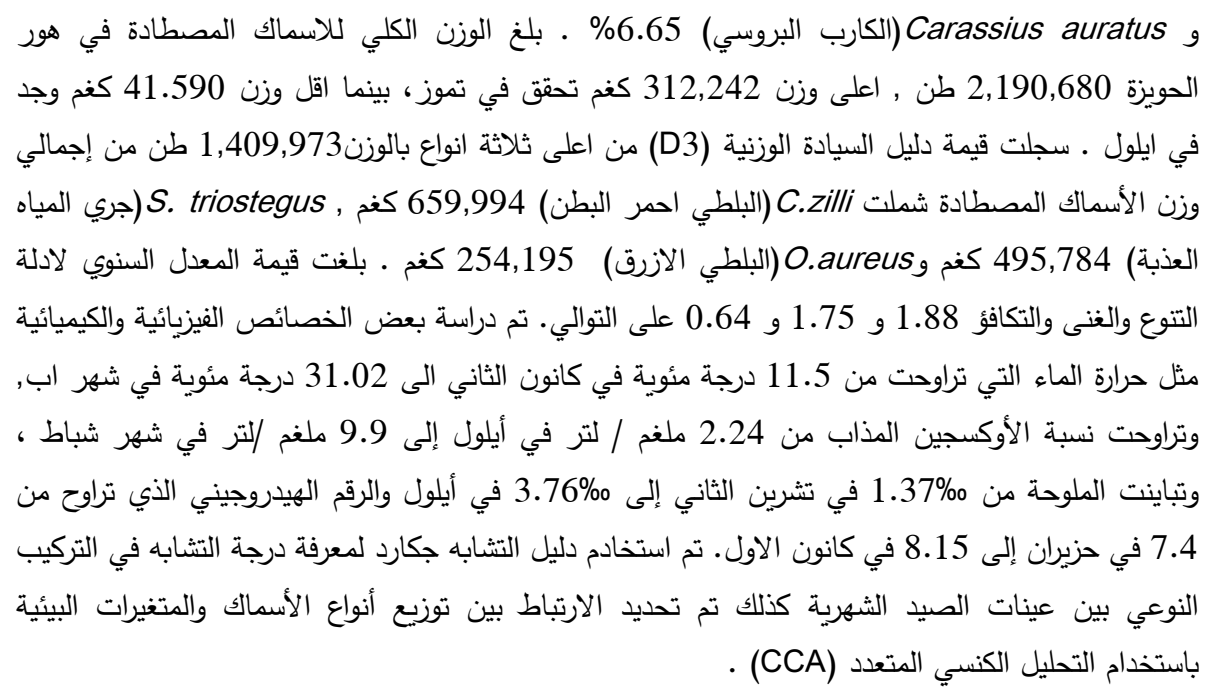

\section{Introduction}

Mesopotamian marshes in southern of Iraq are the biggest complex of wetlands in Iraq and one of the most important aquatic systems in the Middle East [1] and in southwest Asia with an area twice the size of the Everglades in Florida [2],covering an area of more than $15,000 \mathrm{~km}^{2}$ representing about $44 \%$ of inland freshwater and oligo-saline water bodies of Iraq[3].These marshes were characterized by thickets of aquatic vegetation, generally consisting of common reed, Phragmites australis and rushes, Typha domingensis [4] and therefore constitute a natural shelters for many of the special birds, fish, buffalo and other aquatic life [5] and major source of inland fisheries (60\%) in Iraq [6].They were the permanent habitat for millions of waterfowls and a flyway for migrating between Siberia and Africa [7].Nevertheless, the marshes are important for economic, social and biodiversity values characterized by frequency of water flows, production of commercially important vegetation and fish, support endangered species and sustain freshwater and marine fish [8].These marshes were encountered various issues during the last three decades amongst them construction of new hydrological projects in upper parts of the Euphrates and Tigris Rivers and drainage activities in the 1990s desiccating the southern marshlands [3].Since mid-2003, great efforts were made to restore the marshlands.

The Mesopotamian Marshlands (Al-Huwaizah marsh) were listed as a World Heritage Site (UNESCO), making them most unique wetlands in the world during the 40th session in the World Heritage Committee under cultural criteria (iii ) and (v) and natural criteria (ix) and (x) in Istanbul in 2016. The UNESCO considered it as one of the natural components of Iraq with an estimated area about 90,663 hectares $\left(906.63 \mathrm{~km}^{2}\right)$ [9].

After inundation the marsh in April 2003, published research papers dealt mostly with the fish species composition, but unfortunately few studies were detected dealing with the fish stock assessment in this marsh as studies [10-12]. There is no published information on the species composition, fish ecology, and fisheries of the Al-Huwaizah marsh until last study by Youns et al.[12] on Um Al-Nia'aj position. The specific objective of the present work is to describe the status of fish assemblage structure of Al-Huwaizah marsh and abundance to compare this with the state of the fish assemblage in this marsh before a decade.

\section{Materials and Methods \\ Description of study area}

This is considered as a first study for nature of fish assemblage in Al-Huwaizah marsh after inscribed on the World Heritage List. Al-Huwaizah marsh lies to the east of the Tigris River, straddling the Iran-Iraq border and lies approximately $70 \mathrm{~km}$ of Al-Ammara city. It extends between $\left(31^{\circ} 00^{\prime}-31^{\circ} 45^{\prime} \mathrm{N}, 47^{\circ} 25^{\prime}-47^{\circ} 50^{\prime} \mathrm{E}\right)$. The area is distributed by $79 \%$ for the Iraqi part and by $21 \%$ for the Iranian part [13]. Its length is about $80 \mathrm{~km}$, from the Iraqi-Iranian borders to the east of the Tigris river from its western part, with wide of $30 \mathrm{~km}$ [14].Thus the average of the size of the marsh is about $2400 \mathrm{~km}^{2}$ which extends to $3500 \mathrm{~km}^{2}$ during the flood season and shrinks to $650 \mathrm{~km}^{2}$ during the season of dryness, which is only applicable to deep water areas. The reservoir of this marsh attains about 7000 billions $\mathrm{m}^{3}$ obtained from the water excess of the nearest Tigris and 2-4 meters above sea level [15]. The marsh is largely fed by two main distributaries departing from the Tigris River near 
AL-Ammarah city, known as Al-Musharah and Al-Kahla rivers. Added to this is water from rainfall, and water from the rivers arriving from Iran, such as the Al-Karkha, Tayib and Duwayaraj Rivers, which empty into Al-Sanna'f marsh and which in turn supplies Al-Huwaizah marsh.

Fish were collected a monthly from four selected stations included Umm Al-Ward ( $\mathrm{N} 31^{\circ} 33^{\prime}$

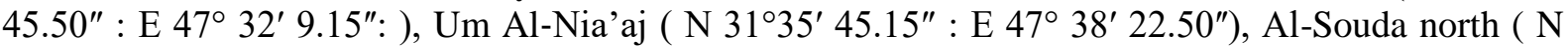
$31^{\circ} 40^{\prime} 22.26^{\prime \prime}$ : E $47^{\circ} 39^{\prime}$ 50.38') and Al-Adaim (N 31 $41^{\prime} 22.36^{\prime \prime}$ : E $47^{\circ} 45^{\prime} 35.40^{\prime \prime}$ ) in Al-Huwaizah marsh from December 2017 to November 2018(Figure -1). Water temperature, dissolved oxygen, salinity and $\mathrm{pH}$ were measured in situ using digital portable WTW Multi-meter model (Multi 350i meter). Water depth was measured by ironic-ruler, which is divided from 0-400 cm. Fish sampling was carried out from each station using seine net $(20 \mathrm{~m}$ long with a $2.5 \mathrm{~cm}$ mesh size), fixed and drifted gill nets $(120 \mathrm{~m}$ long with $2.5 \mathrm{~cm}$ to $10 \mathrm{~cm}$ mesh size) and electro-fishing by generator engines(provides 300-400V and 10A), it was used in the places where the vegetation very density and can not be caught. Specimens were immediately transported to the laboratory by box with crushed ice. The weight of fish was calculated monthly for each caught species in gram and Kilogram using a balance type Sartorius (BL3100). Fish were counted and classified in to species based on [16-19].

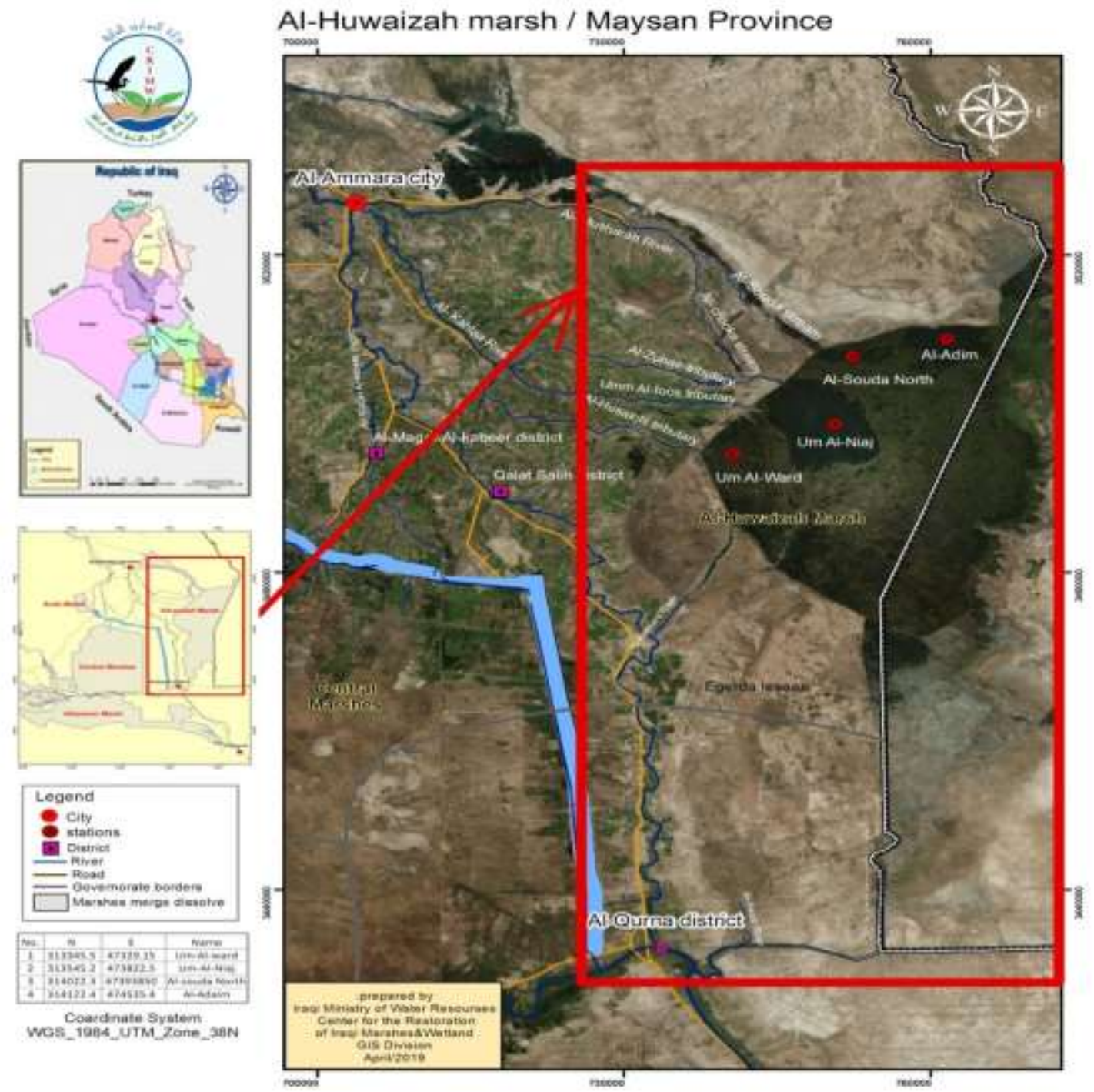

Figure 1- Al-Huwaizah marsh location in Maysan province southern of Iraq [20].

The relative abundance $(\mathrm{Ra} \%)$ was calculated from the equation $n i / N \times 100$ [21]. Shannon-Weaver index of diversity obtained by the following equation $H=-\Sigma p i \operatorname{lnpi}$ [22]. The species richness was calculated using the equation $D=(S-1) / \ln N$ [23]. The evenness is $J=H / \ln \mathrm{S}$ [24]. The three most abundant species determined by the following equation $D 3=\left(\sum_{i=1}^{3} p i\right) \times 100$ [25]. Jaccard Similarity 
Index (Ss\%) was used to determine the degree of similarity among study months by the following equation $I S_{J}=[a /(a+b+c)] \times 100[26]$.

\section{Statistical analysis}

The data of this study treated by using two statistical programs, statistical package for social sciences (SPSS) version 22 for F-test, the mean \pm SD (standard deviation) for water parameters among stations and months by using analysis of variance (ANOVA), correlation between water parameters and number of fish species and individuals. Whereas the multiple linear correlation analysis carried out on water parameters and fish to verify if there is any significant relationship by applying the canonical correspondence analysis(CCA)of ecological data using CANOCO program [27].All these tests were conducted at the probability of 0.05 .

\section{Results and Discussion}

\section{Ecological factors}

It was found there are no significant differences $(F=0.67,0.85,0.59$ and $0.38, p>0.05)$ among the four sampling stations with the values of water temperature, dissolved oxygen, salinity and $\mathrm{pH}$, when they were measured. The monthly variations in the mean values of these factors were shown in (Figure-2).Water temperature values were varied, where the lowest value $11.5^{\circ} \mathrm{C}$ recorded in January, while the highest value $31.02^{\circ} \mathrm{C}$ revealed in August, where mean and SD value was 22.8 \pm 7.23 . Dissolved oxygen values ranged from $2.24 \mathrm{mg} / \mathrm{l}$ in September to $9.9 \mathrm{mg} / \mathrm{l}$ in February, mean and SD value $6.72 \pm 2.34$. Also the salinity values ranged from $1.37 \%$ in November to $3.76 \%$ in September, mean and $\mathrm{SD}$ value $2.9 \pm 0.95$. Whereas narrow fluctuation of $\mathrm{pH}$ was observed during the study period, where the highest mean value of 8.15 was tested in December, while lowest average value 7.4 was examined in June, mean and SD value $7.7 \pm 0.31$.

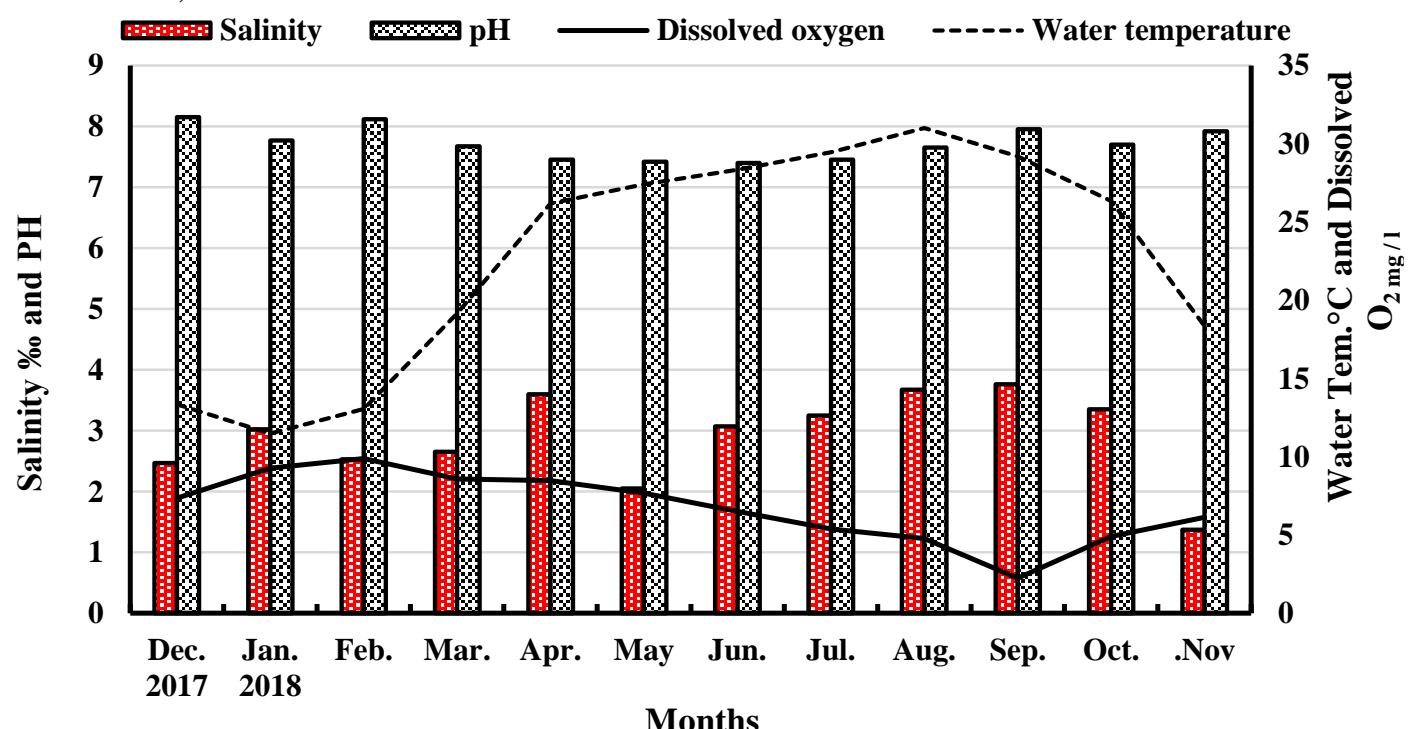

Figure 2- Monthly variations in the means of some ecological factors of Al-Huwaizah marsh

On the other hand, the average water depth in Al-Huwaizah marsh ranged from $33 \mathrm{~cm}$ in September to $98 \mathrm{~cm}$ in February, where maximum depth $118 \mathrm{~cm}$ was found in April at station 2, while minimum depth $27 \mathrm{~cm}$ was reported in September at station 4.Significant differences $(P \leq 0.05)$ were detected in water depth among study stations.

Fish assemblage structure and composition were distinctly varied in the marsh which corresponds to hydrological and geomorphic differences. However, fish distributions associated with closely correspond to habitat features. Water temperature is one necessary of environmental variables affecting the distribution and abundance of different fish, the feeding activity and food consumption are affected by temperature because of the lower temperature than ideal limits [28]. Also, salinity may also participate in differences of distribution and abundance of fish species and their composition inside the marsh. Moreover, fish presence, distribution, and movement along aquatic environments are influenced by overlapping of living and non-living factors either directly or indirectly [29] thus declare that it is difficult to base species existing on a specific environmental factor [30]. 


\section{Species composition}

Altogether, nineteen fish species belonging to nine families and seventeen genera were collected from four studied stations in Al-Huwaizah marsh (Table -1). Cyprinidae was the most dominated family in terms of number of species represented by nine species followed by Cichlidae family ( 3 species), whereas Mugilidae, Siluridae, Heteropneustidae, Bagridae, Mastacembelidae, Cyprinodontidae and Poeciliidae families were contained one species each.

Table 1- Monthly variations in relative abundance for fish species which collected of Al-Huwaizah marsh during study period

\begin{tabular}{|c|c|c|c|c|c|c|c|c|c|c|c|c|c|c|}
\hline \multirow{2}{*}{ Family } & \multirow{2}{*}{ Species } & \multirow{2}{*}{$\begin{array}{c}\text { Dec } \\
2017 \\
\end{array}$} & Jan & Feb & Mar & Apr & May & Jun & Jul & Aug & Sep & Oct & Nov & Total \\
\hline & & & \multicolumn{12}{|c|}{2018} \\
\hline Mugilidae & Planiliza $a b u+$ & 37.57 & 40.64 & 39.62 & 35.79 & 38.15 & 41.23 & 43.71 & 40.87 & 39.27 & 33.25 & 29.34 & $\begin{array}{c}35.9 \\
1\end{array}$ & 38.2 \\
\hline Cichlidae & Coptodon zillii * & 38.01 & 34.61 & 32.32 & 33.84 & 28.8 & 26.4 & 20.83 & 16.82 & 21.29 & 15.11 & 18.17 & 15.4 & 29.41 \\
\hline Cyprinidae & Carassius auratus * & 4.16 & 2.69 & 6.57 & 7.8 & 9.62 & 8.4 & 8.24 & 6.1 & 9.78 & 11.59 & 10.9 & 9.05 & 6.65 \\
\hline Siluridae & Silurus triostegus + & 4.27 & 4.63 & 4.89 & 4.88 & 6.11 & 6.14 & 5.93 & 7.26 & 8.36 & 8.31 & 6.73 & 5.5 & 5.52 \\
\hline Cichlidae & $\begin{array}{c}\text { Oreochromis } \\
\text { aureus } *\end{array}$ & 3.37 & 2.45 & 2.78 & 3.09 & 3.72 & 3.46 & 3.43 & 4.37 & 7.41 & 8.82 & 7.81 & 8.02 & 3.72 \\
\hline Cyprinidae & $\begin{array}{c}\text { Carasobarbus } \\
\text { luteus }+\end{array}$ & 2.58 & 3.24 & 2.85 & 2.76 & 1.81 & 2.64 & 3.9 & 5.37 & 0.95 & & & 4.38 & 3.07 \\
\hline $\begin{array}{c}\text { Heteropneu } \\
\text { stidae }\end{array}$ & $\begin{array}{l}\text { Heteropneustes } \\
\text { fossilis * }\end{array}$ & 1.13 & 1.58 & 1.35 & 1.87 & 2.71 & 1.8 & 1.66 & 2.83 & 4.26 & 12.34 & 9.02 & 6.44 & 2.35 \\
\hline Cyprinidae & $\begin{array}{c}\text { Alburnus } \\
\text { mossulensis }+\end{array}$ & 1.79 & 2.09 & 2.24 & 2.14 & 2.66 & 2.76 & 2.75 & 2.71 & 1.89 & 2.52 & 2.69 & 1.87 & 2.31 \\
\hline Cyprinidae & Leuciscus vorax + & 2.05 & 2.28 & 2.02 & 1.98 & 2.39 & 2.72 & 2.24 & 2.44 & & & & 2.43 & 2.1 \\
\hline Cichlidae & $\begin{array}{c}\text { Oreochromis } \\
\text { niloticus } *\end{array}$ & 1.08 & 0.98 & 1.03 & 2.03 & 0.48 & 0.45 & 1.01 & 2.38 & 1.74 & & 0.94 & 1.12 & 1.23 \\
\hline Cyprinidae & $\begin{array}{c}\text { Carasobarbus } \\
\text { sublimus }+ \\
\end{array}$ & 0.92 & 1.11 & 0.96 & 0.92 & 0.63 & 0.53 & 1.37 & 2.62 & & & & 1.58 & 1.11 \\
\hline Cyprinidae & $\begin{array}{c}\text { Hemiculter } \\
\text { leucisculus } *\end{array}$ & 0.63 & 0.74 & 1.06 & 1 & 1.17 & 1.27 & 0.94 & 0.75 & 1.1 & 1.01 & 1.35 & 1.21 & 0.94 \\
\hline Bagridae & Mystus Pelusius + & & & & & & & 1.41 & 1.99 & 1.89 & 6.8 & 9.83 & 5.13 & 0.94 \\
\hline Cyprinidae & Cyprinus carpio * & 0.69 & 0.67 & 0.52 & 0.43 & 0.21 & 0.25 & 0.25 & 0.36 & 0.95 & & 2.28 & 1.68 & 0.56 \\
\hline $\begin{array}{c}\text { Cyprinodon } \\
\text { tidae }\end{array}$ & Aphanius dispar + & & 0.7 & 0.61 & 0.49 & 0.58 & 0.58 & 0.7 & 0.66 & 0.95 & & & & 0.49 \\
\hline Cyprinidae & $\begin{array}{c}\text { Acanthobrama } \\
\text { marmid }+\end{array}$ & 0.45 & 0.55 & 0.27 & 0.38 & 0.53 & 0.62 & 0.8 & 0.51 & & 0.25 & 0.54 & & 0.46 \\
\hline $\begin{array}{c}\text { Mastacemb } \\
\text { elidae }\end{array}$ & $\begin{array}{c}\text { Mastacembelus } \\
\text { mastacembelus }+\end{array}$ & 0.5 & 0.38 & 0.39 & 0.08 & 0.11 & 0.25 & 0.47 & 1.57 & & & & & 0.44 \\
\hline Poeciliidae & $\begin{array}{c}\text { Gambusia } \\
\text { holbrooki } *\end{array}$ & 0.53 & 0.48 & 0.42 & 0.38 & 0.27 & 0.29 & 0.18 & 0.15 & 0.16 & & 0.4 & 0.28 & 0.34 \\
\hline Cyprinidae & $\begin{array}{c}\text { Mesopotamichthys } \\
\text { sharpeyi }+\end{array}$ & 0.26 & 0.17 & 0.1 & 0.14 & 0.05 & 0.21 & 0.18 & 0.24 & & & & & 0.16 \\
\hline
\end{tabular}

+ Native species ; * Alien species

The monthly fluctuations in number species and individuals were shown in (Figure-3). The number of species ranged from 10 species in September to 19 species in June and July. Generally, the number of fish captured species increased from December till July. A total of 28959 individual of fish were caught from Al-Huwaizah marsh during the study period, they ranged from 397 fish in September to 4166 fish in January.

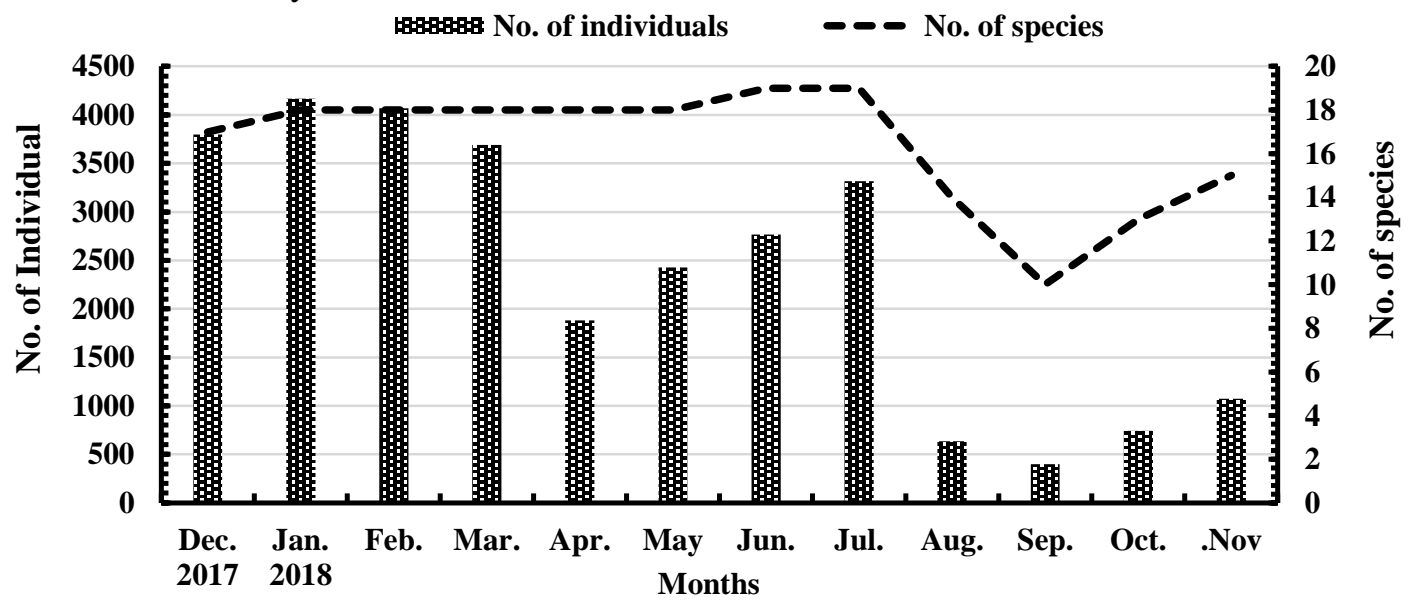

Figure 3-Monthly variations in the total number of caught fish species and individuals at Al-Huwaizah marsh during study period 
The fish species of Al-Huwaizah marsh broadly classified into 11 native and 8 of alien freshwater fish species. The monthly variations in these categories are given in (Figure-4). The native fish species constituted $57.89 \%$ of the total number of fish species and varied from 5 species in both September and October months to 11 species in June and July months, whereas the alien species formed $42.11 \%$ and ranged from 5 species in September to 8 species in all other months.

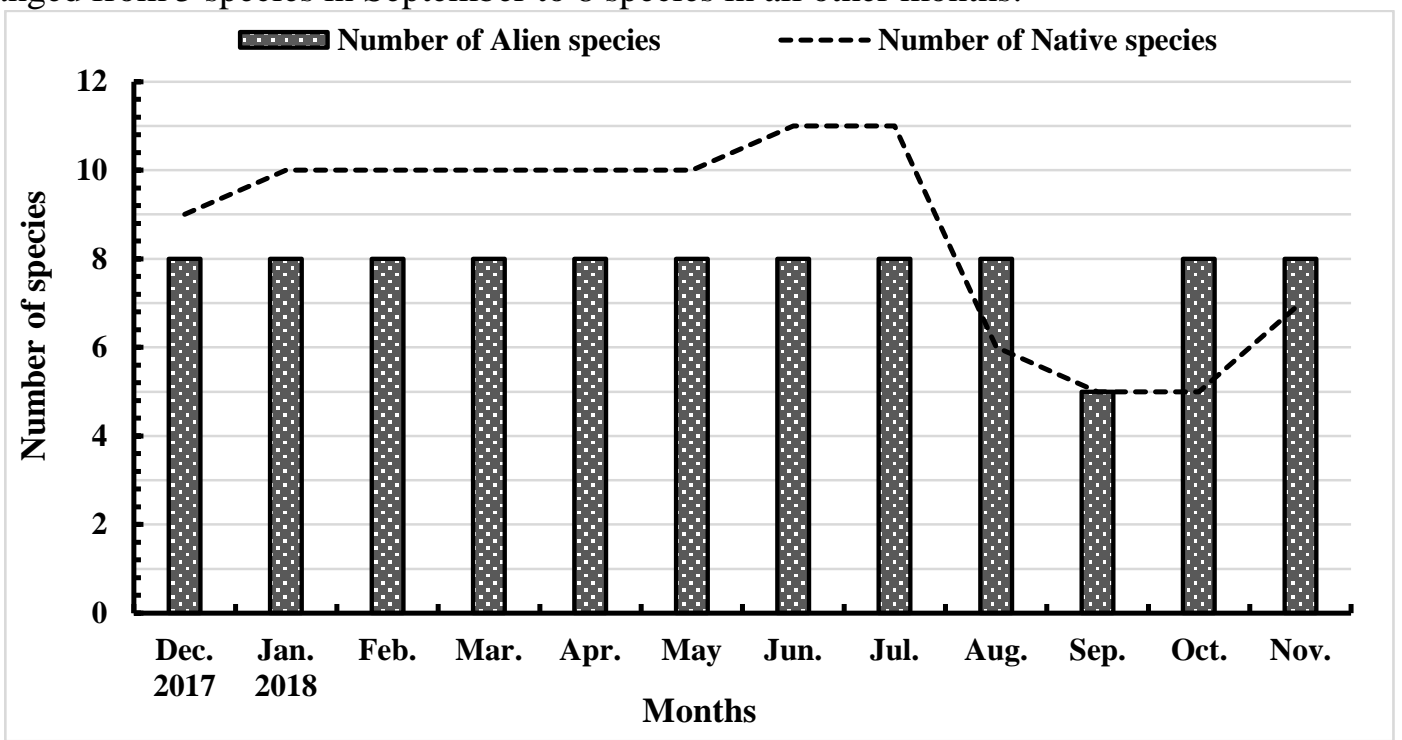

Figure 4- Monthly variations in number of the native and alien fish species of Al-Huwaizah marsh

The results of the present study revealed that the fish assemblage was clearly shifted in the present of alien and the dominancy species and the fish diversity compared with the previous status. The number of native species is naturally declining, accompanied by an increase in number of alien species, that represented as a form of disturbances coming from human influences, and entering these species represents the increasing biological disturbance with deteriorating water quality and the environment Mohamed et al.[31], thus the increase in proportion of alien species coincides with the high percent of individuals of the tolerant species this supported study Costa and Schulz [32] where showed that the tolerant species are the last to leave the water surface at the deterioration time.

Overall, this study recorded highest number of native and alien of fish species in Al-Huwaizah marsh.

The native fish recorded 15870 individual forming $54.8 \%$, the highest number 2243 individual done in December 2017 comprised 14.13\%, while the lowest number 203 individual presented in September by $1.28 \%$ of the total number of the native fish individuals. Whereas the alien fish achieved 13089 individual giving a percentage $45.2 \%$ of the total number of fish captured. The highest number 2169 fish collected in February formed 16.57\%, while lowest number 194 fish finding during September comprised $1.48 \%$ of the total number of alien fish individuals . In addition the highest proportion of native fish species that recorded in the Al-Huwaizah marsh included P. abu $38.2 \%$;

S. triostegus $5.52 \%$; C. luteus $3.07 \%$; A. mossulensis $2.1 \%$ and $L$. vorax $2.1 \%$, whereas the highest proportion of alien fish species included C. zilli $29.41 \%$; C. auratus $6.65 \%$; O. aureus $3.72 \%$; H. fossilis $2.35 \%$ and $O$. niloticus $1.23 \%$ (Table -1 ).

Planiliza abu and Coptodon zillii have an overall numerical dominance comprised $67.61 \%$ of a total number of fish caught in the prersent study. One of the reasons that led to the increase these two species their highly tolerant to environmental conditions and ability to adapt themselves to new environments with rapid reproduction and easy distribution [33].The inland waters in Iraq have clearly faced several drastic variations which included habitat alterations, entry alien species and declines in native fish communities [18,34]. As well as, Hussein 2010[35] revealed the ability of alien species in influencing on composition the fish community through competition, predation and interference with resident local fish. However, these changes in the structure of fish assemblage in Al-Huwaizah marsh due to the decline in discharge rates of Tigris River Al-Mahmood et al. [36]. Moreover, Welcomme [37] stated that fish assemblage in rivers, lakes and reservoirs vary widely in the abundance from year to year, and these variations are in response to fluctuations in precipitation and flood strength. 
The number of alien fish species was increased considerably comparison with the past findings reported earlier on the marsh. Moreover, two new species were recorded for the first time in AlHuwaizah marsh southern Iraq, at Maysan Province namely $C$. sublimes of native species which first recorded by Mohamed et al.[38] from the upper reaches of the Shat al-Arab River, and other $O$. niloticus of alien species, this species was first recorded by Al-Faisal and Mutlak [39] in Shatt AlArab River, at Basrah Province, Iraq. In addition this species was not recorded in the previous studies conducted on Al-Huwaizah marsh.

\section{Relative abundance}

The highest proportions of captured fish families included Mugilidae family in the first rank where comprised $38.2 \%$; Cichlidae family get the second rank with $34.36 \%$; Cyprinidae family was rank at third level by $17.36 \%$; Siluridae family ranked fourth gave percent $5.52 \%$ and Heteropneustidae family came in the fifth rank formed $2.35 \%$, whereas the lowest proportions included Bagridae, Cyprinodontidae, Mastacembelidae and Poeciliidae families and comprised $0.94 \% ; 0.49 \% ; 0.44 \%$ and $0.34 \%$, respectively.

According to dominance index (D3) there are three species formed $74.26 \%$ of the total number of fish caught were in the order following : Planiliza abu which composed $38.2 \%$ of the total catch, it varied from $29.34 \%$ in October to $43.71 \%$ in June. Coptodon zillii comprising $29.41 \%$, it fluctuated from $15.11 \%$ in September to $38.01 \%$ in December and Carassius auratus was formed $6.65 \%$, its relative abundance ranged from $2.69 \%$ in January to $11.59 \%$ in September (Table -1).

Degradation of water quality in the southern marshes led to several Cyprinid species disappearance or substantially decreased in abundance, such as Arabibarbus grypus, Luciobarbus xanthopetrus, Luciobarbus kersin, Mesopotamichthys sharpeyi [40, 41]. Furthermore, Hughes and Whittier [42] stated that the native species represent the basic building blocks of a fish assemblage, and are a key component of diversity and the alien species indicate biological pollution and a serious diversion from natural conditions, especially when they constitute a substantial percentage of the assemblage, and including when they are deliberately introduced. The extremely tolerant species are the last to disappear in response do environmental degradation Costa and Schulz[32]. Researchers have commonly observed habitat degradation facilitating the underlying mechanisms causing the loss of native fish diversity, the temporal replacement of specialized native fish by alien fish [43, 44].

\section{Quantities of fishing}

The results of the present study showed there are monthly and total variations in caught fish families (Table -2). The total weight of fish captured in Al-Huwaizah marsh reached to 2,190,680 tan. The highest weight 312,242 kg collected in July, while lowest weight 41,590 kg done in September. Nine of fish families captured in the study area included Cichlidae family which occupied the first rank with total weight amounted 996,723 kg comprised 45.5\% where varied from 13,890 $\mathrm{kg}$ in September to $148,428 \mathrm{~kg}$ in February; Siluridae family came in the second rank with total weight amounted 495,784 kg forming $22.63 \%$, it ranged from 15,646 kg in September to 76,954 kg in July; the third rank was occupied by Cyprinidae family achieved $384,855 \mathrm{~kg}$ where varied from $3,372 \mathrm{~kg}$ in September to $61,888 \mathrm{~kg}$ in July; Mugilidae family came in the fourth rank get $231,320 \mathrm{~kg}$ with $10.56 \%$, the highest weight $44,550 \mathrm{~kg}$ in July, and lowest weight $3,480 \mathrm{~kg}$ in September and Heteropneustidae family occupied the fifth rank of $48,184 \mathrm{~kg}$ comprised $2.2 \%$, where laid between $1,929 \mathrm{~kg}$ in August and 7,080 kg in July, whereas Bagridae, Mastacemblidae, Cyprinodontidae and Poeciliidae families formed $0.83 \%, 0.68 \% ., 0.03$ and $0.0 \%$ respectively, from the total weight of fish caught within Al-Huwaizah marsh .

According to dominance index (D3) there are three species recorded 1,409,973 tan of the total weight of fish caught were in the order following : C.zilli achieved as a highest weight where reached to $659,994 \mathrm{~kg}$ and varied from $3,957 \mathrm{~kg}$ in September to $123,462 \mathrm{~kg}$ in February ; S. triostegus achieved 495,784 kg and ranged from15,646 kg in September to 76,954 kg in July; O.aureus recorded $254,195 \mathrm{~kg}$ laid between 9,933 kg in September and 48,974 kg in July. 
Table 2- Monthly variations in weight $(\mathrm{Kg})$ of fish caught at Al-Huwaizah marsh during study period

\begin{tabular}{|c|c|c|c|c|c|c|c|c|c|c|c|c|c|}
\hline \multirow{2}{*}{ The Species } & Dec. & Jan. & Feb. & Mar. & Apr. & May & Jun. & Jul. & Aug. & Sep. & Oct. & Nov. & \multirow[t]{2}{*}{ Total } \\
\hline & 2017 & \multicolumn{11}{|c|}{2018} & \\
\hline C. zillii & 105,576 & $\begin{array}{c}110,43 \\
6 \\
\end{array}$ & $\begin{array}{c}12346 \\
2\end{array}$ & $\begin{array}{c}107,44 \\
5 \\
\end{array}$ & 49,823 & 56,338 & 39,758 & 34,820 & 8,691 & 3,957 & 9,053 & 10,635 & 659,994 \\
\hline S. triostegus & 42,576 & 59,651 & 58,752 & 50,376 & 33,964 & 41,934 & 45,823 & 76,954 & 25,472 & 15,646 & 22,917 & 21,719 & 495,784 \\
\hline O. aureus & 15,397 & 11,148 & 16,648 & 18,006 & 1,2894 & 23,130 & 33,306 & 48,974 & 14,284 & 9,933 & 18,699 & 31,776 & 254,195 \\
\hline P. $a b u$ & 18,148 & 19,475 & 19,186 & 18,926 & 1,1381 & 28,268 & 37,280 & 44,550 & 8,671 & 3,480 & 7,954 & 14,001 & 231,320 \\
\hline C. auratus & 11,077 & 7,760 & 18,721 & 18,782 & 1,2845 & 13,425 & 15,471 & 14,322 & 4,291 & 2,848 & 5,975 & 7,708 & 133,225 \\
\hline O. niloticus & 3,066 & 3,138 & 8,318 & 16,320 & 1,727 & 3,223 & 11,218 & 26,479 & 3,223 & & 2,127 & 3,695 & 82,534 \\
\hline L. vorax & 8,311 & 9,563 & 9,511 & 8,234 & 4,360 & 6,558 & 8,155 & 13,118 & & & & 4,402 & 72,212 \\
\hline C. carpio & 7,105 & 8,379 & 6,685 & 6,071 & 1,684 & 2,613 & 3,662 & 5,919 & 2,552 & & 6,442 & 6,268 & 57,380 \\
\hline C. luteus & 5,824 & 6,828 & 5,758 & 5,637 & 2,309 & 3,786 & 7,038 & 13,918 & 4610 & & & 3,375 & 54,934 \\
\hline H. fossilis & 3,919 & 3,973 & 3,286 & 4,373 & 3,029 & 3,671 & 4,015 & 7,080 & 1,929 & 3,481 & 4,624 & 4,804 & 48,184 \\
\hline C. sublimus & 2,081 & 2,327 & 1,937 & 1,880 & 0,815 & 0,797 & 2,526 & 6,794 & & & & 1,172 & 20,329 \\
\hline M. Pelusius & & & & & & & 2,769 & 4,201 & 0,720 & 1,721 & 5,052 & 3,647 & 18,110 \\
\hline M. sharpeyi & 2,817 & 2,542 & 1,460 & 1,803 & 0,348 & 2,365 & 2,162 & 3,292 & & & & & 16,789 \\
\hline $\begin{array}{c}M . \\
\text { mastacembelus } \\
\end{array}$ & 1,213 & 1,107 & 1,246 & 0,271 & 0,227 & 1,360 & 2,403 & 7,184 & & & & & 15,011 \\
\hline H. leucisculus & 0.357 & 0.448 & 1,152 & 2,261 & 1,825 & 2,464 & 2,212 & 1,725 & 0,544 & 0,278 & 0,690 & 0,898 & 14,854 \\
\hline A.mossulensis & 0.849 & 1,197 & 1,397 & 1,193 & 0,794 & 1,057 & 1,426 & 2,450 & 0,305 & 0,229 & 0,566 & 0,572 & 12,035 \\
\hline A. marmid & 0.229 & 0.339 & 0,198 & 0,254 & 0,190 & 0,228 & 1,177 & 0,350 & & 0,17 & 0,115 & & 3,097 \\
\hline A. dispar & & 0.89 & 900 & 0,71 & 0,51 & 0,90 & 0,168 & 0,113 & 0,21 & & & & 0,693 \\
\hline G. holbrooki & 0,04 & 0,028 & 0,028 & 0,028 & 0,011 & 0,011 & 0,008 & 0,008 & 0 & 0 & 0 & 0 & 0.162 \\
\hline Total Weight & 228,545 & $\begin{array}{c}248,40 \\
0\end{array}$ & $\begin{array}{c}277,80 \\
7\end{array}$ & $\begin{array}{c}261,90 \\
3 \\
\end{array}$ & $\begin{array}{c}138,26 \\
6\end{array}$ & $\begin{array}{c}191,30 \\
7 \\
\end{array}$ & $\begin{array}{c}220,56 \\
9\end{array}$ & $\begin{array}{c}312,24 \\
3\end{array}$ & 71,164 & 41,590 & 84,214 & $\begin{array}{l}672 \\
114 \\
\end{array}$ & $\begin{array}{c}2,190,68 \\
0 \\
\end{array}$ \\
\hline
\end{tabular}

Al-Huwaizah marsh witnessed significant monthly fluctuations in fishing quantities for families and individual species. The highest weight recorded in July that due to the large numbers of fish caught than the other months, also the changes in temperature and salinity concentration have an effect on mass of fish, while the lowest quantities caught were in September, August and October months respectively, because of the lower level of water in these month, decrease in the number of fish caught individuals in the study area, in addition the disappearance of some sensitive species as $M$. mastacembelus, $M$. sharpeyi and $L$. vorax with the increase in the number of alien species, thus caused a large variation between the quantities of fishing during the study months, and this could be caused by unfavorable environmental parameters, especially higher salinity and changed hydrological conditions Mohamed et al.[45]. Also, the fishery has also been associated with the period of fish movement, feeding activity and the reproduction of local species [46].

There are negative insignificant correlation $(\mathrm{P}>0.05)$ between water temperature and the total number of species $(\mathrm{r}=-0.561)$; negative significant correlation $(\mathrm{P} \leq 0.05)$ between water temperature and total number of individuals $(\mathrm{r}=-0.654)$; positive significant correlation $(\mathrm{P} \leq 0.05)$ for dissolved oxygen with the total number of species and total number of individuals $(r=0.788$ and $r=0.731)$ respectively, water depth showed positive significant correlation $(\mathrm{P} \leq 0.05)$ with the total number of species and total number of individuals $(\mathrm{r}=0.815$ and $\mathrm{r}=0.698)$ respectively, salinity showed negative insignificant correlation $(\mathrm{P}>0.05)$ with the total number of species and total number of individuals $(\mathrm{r}=$ - 0.347 and $\mathrm{r}=-0.315)$ respectively, also $\mathrm{pH}$ showed negative insignificant correlation $(\mathrm{P}>0.05)$ with the total number of species and total number of individuals $(r=-0.383$ and $r=-0.196)$ respectively.

\section{Fish ecological indices}

Monthly variations in diversity, richness and evenness indices of fish assemblage in Al-Huwaizah marsh are illustrated in (Figure - 5). The diversity index $(\mathrm{H})$ fluctuated from 1.66 in January to 2.12 in November, with overall value 1.88. The richness index (D) changed from 1.5 in September to 2.27 in June, with overall value 1.75 . In addition the evenness index $(\mathrm{J})$ ranged from 0.57 in January to 0.83 in September, with overall value 0.64 . The correlation coefficient ( $\mathrm{r}$ ) finding there are significant positive correlation $(\mathrm{P} \leq 0.05)$ between water temperature with both evenness index $(\mathrm{J})(\mathrm{r}=0.595)$ and diversity index $(H)$ where $r$ value $(r=0.361)$, it showed negative correlated with richness index (D) $(r=-$ 0.397), whereas dissolved oxygen showed significant positive correlation $(\mathrm{P} \leq 0.05)$ with richness index (D)where $r$ value $(r=0.684)$ and negative correlated with evenness index $(J)$ and $r$ value $(r=-0.754)$. 


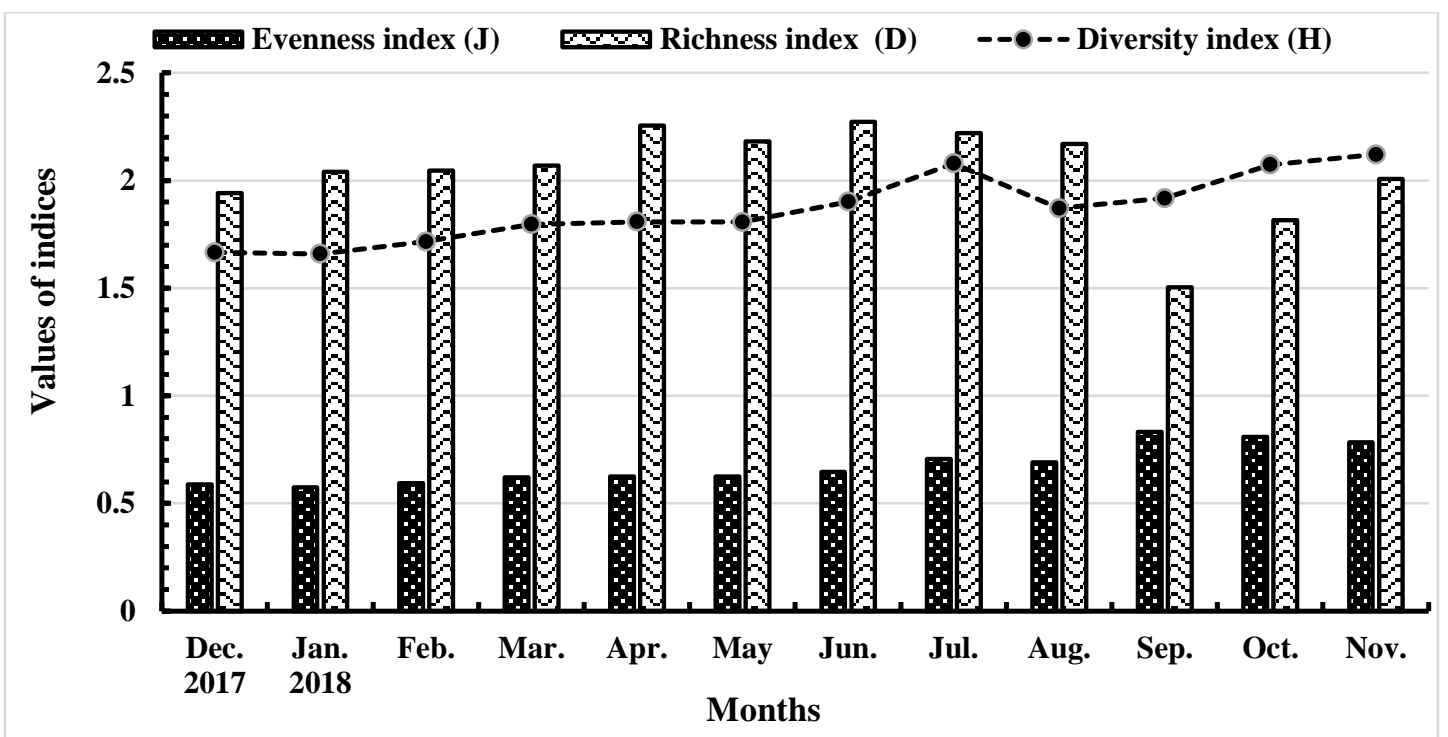

Figure 5- Monthly variations in the ecological indices values of Al-Huwaizah marsh during the study period

There are seasonal changes in fish diversity in the marsh and the richness indices had a general tendency to show high values during the period from April to September which could be attributed largely to the increase in alien fish individuals. This result is supported by the positive significant correlations $(\mathrm{P} \leq 0.05)$ between the number of species and dissolved oxygen $(\mathrm{r}=0.788)$, and negative insignificant correlations $(\mathrm{P}>0.05)$ with salinity $(\mathrm{r}=-0.429)$. The abundance of alien species has led to an increase in the richness, evenness and diversity indices and created seasonal fluctuation in the relative abundance Hussain et al.[47]. Whereas, the rising discharge of water Tigris River shares in the presence variation in composition of fish community in Al-Huwaizah marsh, whereas this result reflected the Richness index (D) value which express on the extent healthy the water body in terms of numerical abundance and fish diversity Rathertm et al.[48].

\section{Canonical correspondence analysis (CCA)}

Figure-6 illustrated the canonical correspondence analysis (CCA) ordination plot which summarized the relationships between the availability of all fish species referred to in a symbol $(\Delta)$ and the physical and chemical properties represented by the arrow in the Al-Huwaizah marsh during the study period. The results indicate to most fish species impacted by the physical and chemical properties in the different percentages except M.pel species which showed positive significant correlation with water temperature and negatively correlated with water depth (Dep), dissolved oxygen (DO) and $\mathrm{pH}$.

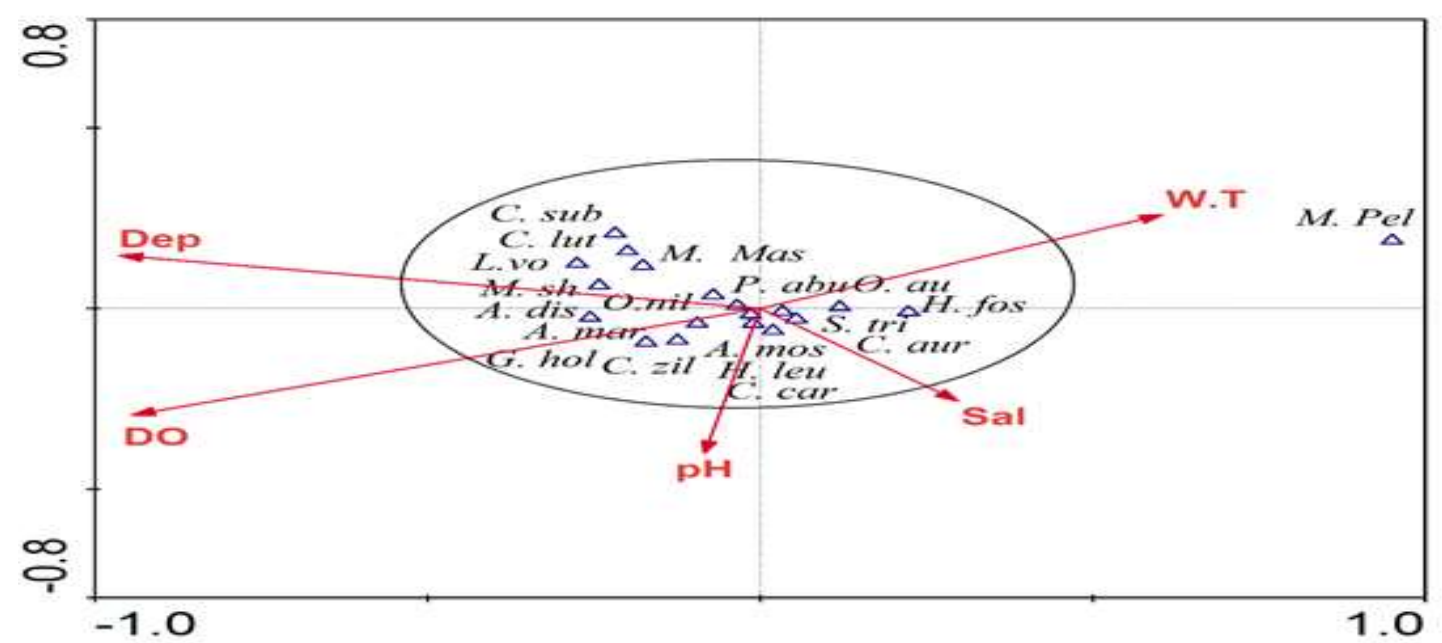

Figure 6- CCA ordination plots showing the relationship among fish species and ecological factors in Al-Huwaizah marsh 


\section{Similarity degree in the species composition using Jaccared Similarity Index (\%Ss)}

The results of similarity in the species composition for fish in Al-Huwaizah marsh using Jaccard Similarity Index showed the presence of three main groups at a similar level of 53\%. The first main group included two secondary groups, the first secondary group consisted of August and November at a similar level of $82 \%$, and the second secondary group included October at a similar level of $77 \%$. The second main group included three secondary groups, the first secondary have June and July at a similar level of $100 \%$. The second secondary group included May, April, March, February, and January at a similar level of $100 \%$, and the third secondary group consisted of December at a similar level of $93 \%$, whereas the third main group has September only (Figure -7).

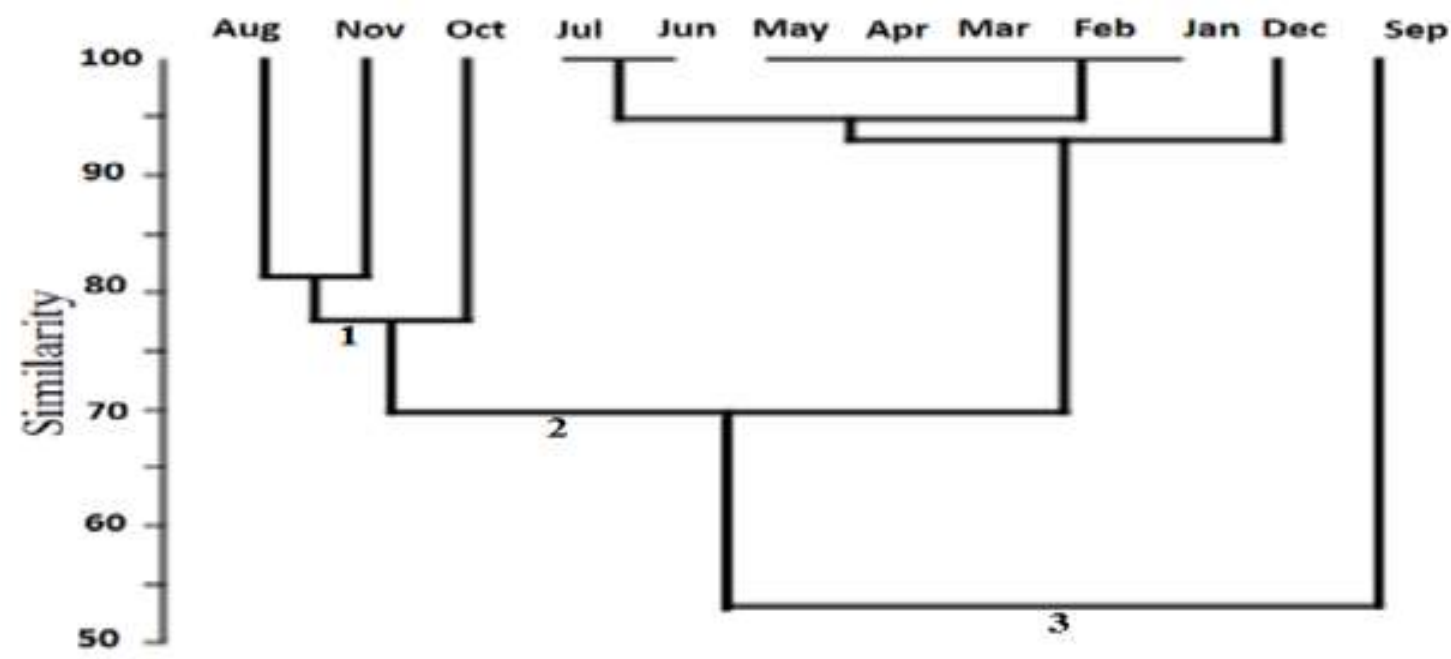

Figure 7- Cluster analysis of similarity degree among monthly fishing samples in Al-Huwaizah marsh using Jaccard Similarity Index (\%Ss)

\section{Conclusions}

The study revealed that the fish assemblage of Al-Huwaizah marsh was clearly altered by increase percents of alien species, and decline in native species compared with the state of the fish assemblage of this marsh before a decade as a result of the decline in the rate of discharge of freshwater during the recent years after the inundation.

\section{References}

1. IMET (Italian Ministry for the Environment and Territory). 2006. Overview of Present Conditions and Current Use of the Water in the Marshlands Area. BOOK 4. Iraq Foundation.175p.

2. Adriansen, H. K. 2006. The Iraqi Marshlands: Is Environmental Rehabilitation Possible. In Papers and Proceedings of Applied Geography Conferences, 29 (214): 214-223.

3. Richardson, C. J. and Hussain, N. A. 2006. Restoring the Garden of Eden: An Ecological Assessment of the Marshes of Iraq. BioScience, 56 (6) :477- 489.

4. Al-Hilli, M. R. A., Warner, B. G. , Asada, T. and Douabul ,A. 2009 . An assessment of vegetation and environmental controls in the 1970s of the Mesopotamian wetlands of southern Iraq. Wetlands Ecology and Management. 17(3): 207-223.

5. Partow, H. 2001. The Mesopotamian marshlands: Demise of an Ecosystem. Nairobi (Kenya): Division of Early Warning and Assessment, United Nations Environment Programme. UNEP publication UNEP/DEWA/ 103p.

6. FAO. 2003. Inland Water Resources and Aquaculture Service, Fishery Resources Division. Review of the state of world fishery resources: inland fisheries. FAO Fisheries Circular. No. 942, Rev.1. Rome. 60p.

7. Evans, M. 2002. The ecosystem. In Nicholson, E., Clark, P. (eds), The Iraqi marshlands: a human and environmental study. Politicos Publishing, London. 201-222. 
8. Maltby, E. 1994. An Environmental and Ecological Study of the Marshlands of Mesopotamia. Draft Consultative Bulletin. Wetland Ecosystem Research Group, University of Exeter. Published by AMAR Appeal Trust, London. 224pp.

9. UNESCO office for Iraq. 2016. The marshlands of Iraq inscribed on UNESCO's world heritagelist.Availablehttp://www.unesco.org/new/en/iraq-office/about thisoffice/singleview/news/the_marshlands_of_iraq_inscribed_on_unescos_world_heritag/

10. Hussain, N.A. , Saoud, H.A. and AL-Shami, E. J. 2008 . Species composition and ecological Indices of Southern Mesopotamica, Marsh Bulletin, 3 (1) : 17-31.

11. Mohamed, A.R.M., Hussain; N.A., AL-Noor, S.S., Mutlak, F.M., AL-Sudani, I. M., Mojer, A, A., Toman, A.J., Abdad , M. A. 2008. Fish assembulge of restored Al-Hawizeh marsh, southern Iraq. Ecohydrology and Hydrobiology. 8 (24) : 375-384.

12. Youns, K.H., AL- Mossawy, M.H. and Jabir, A.A. 2011. Composition structure of fish assemblage in Um Alnaaj, Al-Hawaizah marsh, Iraq. Basrah Res. J. (Scientific), 73 (1) : 49-59.

13. Domad, Z. H. 2008. A Comparative Study of Hawizeh marsh by Use of Remote Sensing and Geographic Information Systems (GIS),M.Sc. Thesis, College of Education Women, Baghdad University. 97p. (In Arabic).

14. Abbas, S.F. 2006. "Application of Hydrodynamic Model in Abu Zirig Marshland", M.Sc. Thesis, University of Al-Mustansiriya.

15. Al-Rubaiy, D.J.1990. Surface water resources in Basrah Province. The Arab Gulf, 22: 145-196.

16. Al-Daham, N. K. 1977. Fishes of Iraq and the Arabian Gulf. Vol. 1.Squaliformes to Atheriniformes. Publication No.9, Centre for Arab Gulf Studies, University Basrah. 546pp.(In Arabic).

17. Fricke, R., Eschmeyer, W. N. and Van der Laan, R. (eds) .2019. Eschmeyer's Catalog of Fishes: Genera,Species,References.indicate(http://researcharchive.calacademy.org/research/ichthyology/ca talog/fishcatmain.asp).

18. Coad, B.W. 2010. Freshwater fishes of Iraq. Pensoft Publishers, Sofia,Bulgaria, 274 p+16 plats.

19. Coad, W.B. 2017. Freshwater Fishes of Iraq. 2017, www.briancoad.com.

20. CRIM (Center of Restoration of the Iraq Marshland). 2019. Map of the Al-Huwaizah marsh southern of Iraq with four stations.

21. Odum, W.A. 1970. Insidious alternation of the estuarine environment .Trans American Fisheries Society. 99: 836-847.

22. Shannon, C.E. and Weaver, W. 1949. The mathematical theory of communication, University of Illions. Press Urbane., $117 \mathrm{p}$.

23. Margalefe, R. 1968. Prespectives in ecology. University of Chicago. Press Chicago, 111p.

24. Pielou, E.C. 1977. Mathematical ecology. John Wiely, New York, 385p.

25. Kwak, T.J. and Peterson, J. T. 2007. Community indices, parameters, and comparisons. Analysis and interpretation of freshwater fisheries data. American Fisheries Society, Bethesda, Maryland: 677-763.

26. Boesch, D.F. 1977. Application of numerical classification in ecological investigation of water pollution U.S. Environmental protection Agency, ecological series EPA-600-13-77-033.

27. Ter Break, C.J.F. 2004. A theory of gradient analysis. IC Prentice Advances in Ecological Research, 34: 235-282.

28. Chorbley, D. 2011. Fish Feeding and Temperature Considerations in Tropical Environmentl Aquatic Environment, 2 (3) : 188 -202.

29. Dudgeon, D. 1995. River regulation in southern China: ecological implications, conservation and environmental management. Regulated Rivers: Research and Management, 11 (1) : 35-54 https:// doi.org/10.1002/rrr.3450110105.

30. Ribeiro,M.C.L.B.,Petrere,M. J.and Juras, A.A. 1995. Ecological integrity and fisheries ecology of the Araguaia-Tocantins River basin,Brazil. Regulated Rivers: ResearchManagement,11: 325-350.

31. Mohamed, A.M., Younis, K. H and. Hameed, E. K. 2017a . Status of Fish Assemblage Structure in the Garmat Ali River, Iraq. IOSR Journal of Agriculture and Veterinary Science. 10(2) :Ver. II. 17-22. www.iosrjournals.org.

32. Costa, P.F., and Schulz, U.H. 2010. The fish community as an indicator of biotic integrity of the streams in the Sinos River basin, Brazil. Brazilian Journal of Biology, 70(4, Suppl.): 1195-1205. https://dx.doi.org/10.1590/S1519-69842010000600009. 
33. Altun, T.; Tekelioglu, N. and Danabas, D. (2006). Tilapia culture and its Problems in Turkey. Journal fisheries and Aquatic Science, 23 (3-4) : 473-478.

34. Jawad, L.A. 2003. Impact of environmental change on the freshwater fish fauna of Iraq. International Journal of Environmental Studies, 60 : 581-593.

35. Hussein, S. A. 2000 . Interaction between introduced exotics and native Icthyofauna and their impact on aquatic ecosystems, southern Iraq. Basrah Journal Science Biology, 18 (2): 125-146.

36. Al-Mahmood, H.K.H; Hassan,W.F., Alhello, A.Z.A., Hammood A.I. and Muhson, N.K. 2015. Impact of low discharge and drought of the water quality of the Shatt Al Arab and Al-Basrah Rivers (South of Iraq). Journal of International Academic Research for Multidisciplinary, 3: 285296.

37. Welcomme, R. L. 2001. Inland fisheries : Ecology and Management. Oxford, UK, Blackwell Science Ltd., Fishing News Books. 358 pp.

38. Mohamed, A. R. M., Abood, A.N. and Jawad, L.A. 2017b. Presence of Carasobarbus sublimus (Coad \& Najafpour, 1997) in the upper reaches of Shatt al-Arab River, Basrah, Iraq. Zoology and Ecology. 27 (1): 30-34.

39. Al-Faisal, A. J. and Mutlak, F. M. 2014 . First record of the Nile tilapia Oreochromis niloticus (Linnaeus,1758),from the Shatt Al-Arab River, Southern Iraq. Mesopotamia Journal Marine science, 29(1): 45- 50.

40. Richardson, C.J., Reiss, P., Hussain, N.A., Alwash, A.J. and D.J. Pool, D.J. 2005. The restoration potential of the Mesopotamian marshes of Iraq. Science, 307: 1307-1311.

41. Mohamed, A. R. M; Hussein, S. A. and Lazem L. F. 2013. Fish assemblage of Garmat Ali River, North of Basrah, Iraq. Basrah Journal of Agriculture Science, 26 (1): 150-166.

42. Hughes, R. M. and Whittier, T. R. 2005 . Biological condition Index development for the lower Truckee River and Eastern sierra Nevada Rivers : Fish Assemblage, Nevada Division of Environmental Protection, 81pp.

43. Olden, J.D. and Poff, N.L. 2003 . Toward a mechanistic understanding and prediction of biotic homogenization. American Naturalist, 162: 442-460.

44. Parks, T.P., Quist, M.C. and Pierce, C.L. 2014 . Historical Changes in Fish Assemblage Structure in Midwestern Nonwadeable Rivers. American Midland Naturalist, 171: 27-53.

45. Mohamed, A. R. M.,Najah A. H. ,Sajed S. A., Falah, M. M. , Ibrahim M. A. and Ahmed, M. M. 2012. Ecological and biological aspects of fish assemblage in the Al-Chybaish marsh, Southern Iraq. Ecohydrology and hydrobiology Journal, 12 (1) : 65-74.

46. Mutlak, F. M. 2012 . Stock assessment of some fish species from East Al-Hammar Marsh, Southern Iraq Ph.D. Thesis .University of Basrah Iraq.195 pp. (In Arabic).

47. Hussain, N. A., Ali, T. S. and Saud, K. D. 1989 . Seasonal fluctuations and composition of fish assemblage in the Shatt-Al-Arab River at Basrah, Iraq. Journal Biology Science Research, 20(1): 139-150.

48. Rathertm D., White, D., Sifneos, J.C. and Hughes, R.M. 1999 . Environment correlates of species richness for native freshwater fishes in Oregon, USA. Journal Biogeogrphy, 26 (2) : 257-273. 